\title{
Effects of Public Expenditure Management Practices on Service Delivery in the Public Sector: The Case of District Assemblies in Ghana
}

\author{
George Kojo Scott \\ Secretary General, African Association for Public Administration and Management \\ (AAPAM), P.O. Box 48677 - 00100, Nairobi, Kenya.
}

Received: April 7, 2019 Accepted: May 4, 2019 Online published: May 13, 2019

doi:10.5296/jpag.v9i2.14617～URL: https://doi.org/10.5296/jpag.v9i2.14617

\begin{abstract}
This research analysed how the public expenditure management as practiced in the District Assemblies of Ghana affect service delivery. The research adopted a mixed-method research approach where qualitative and quantitative data were gathered using questionnaires, interviews, focus group discussions and document analysis. Multistage sampling was used to pick the respondents for the questionnaires, key interview informants and the participants in the focus group discussions. Thirty four out of 170 district assemblies which existed by 2008 were sampled. Participants in the study included 612 District Assembly (DA) officials, 1020 citizens, 28 national/regional officials and 20 participants in focus group discussions. Quantitative data, measured by using five-point Likert scaled-items, were analysed using descriptive statistics and regression while qualitative data were examined thematically. The study established that expenditure management practices had positive significant influence on service delivery. The study recommends that, the DAs should prioritize expenditures to key service delivery areas such as; those that enhance poverty reduction, improve on Human Capital index and strengthen Innovations practices. DAs should strengthen electronic, automation and appropriate technologies for better expenditure management and service delivery. There should be laws to ensure stiffer penalties and enforcement of sanctions on those involved in malpractices in public expenditure management practices, while persistent efforts are made to implement recommendations of Auditor General's reports on DAs expenditures management practices.
\end{abstract}

Keywords: public financial management, public expenditure management practices, service delivery, district assemblies, equity 


\section{Introduction}

Scott (2016) established that public financial management is a mix of interlinked systems, processes and practices which include budgeting, revenue mobilization, public expenditure management, financial reporting, auditing and PFM regulatory framework. This paper focused on public expenditure management practices and how they affect service delivery in Ghana's District Assemblies. Several authors have attempted to explain what qualifies as public expenditure, among them, Adams (2006) who posits that public (government) expenditure refers to the expenses that are incurred by government in running its affairs. In addition, Bhatia (2009) as well as Adejoh and Sule (2013) have held that government expenditures are the expenses incurred for the maintenance of good governance in the interests of the society as well as the economy in general.

Abba and Kakanda (2017) contend that every government has numerous objectives to achieve that include securing of lives and properties, provision of infrastructure and other social amenities, creating an enabling business environment, employments creation and jobs protection among others, to its citizens. Abba and Kakanda add that government expenditures include money spent on security, payment of salaries, payments for contracts, health care services, maintenance of law and order, and building of schools and provision of educational facilities. Bhatia (2009) however contends that with the expanding activities of the state and the growing complications of modern government functions, it is becoming increasingly difficult to make a clear distinction between expenditure ascribed to maintenance of the government itself and those incurred to benefit society and the economy. In line with Bhatia's contention, Akrani (2011) also argued that public expenditure is spending made by the national government on collective needs and wants such as pension, services, and infrastructure. Since the 20th century, according to Akrani, public expenditure has shown an increasing trend.

Despite the varied explanations describing similar issues, there is lack of consensus on a single terminology to authoritatively describe government expenditure among the authors (including Campos \& Pradhan, 1996; Diamond, 2000; Lienert, 2003; Premchand, 1993). Several terms such as public expenditure, public expenditure management as well as public expenditure and payment practices have been used interchangeably in the available literature. This paper adopted the term Public Expenditure Management (PEM) practices to refer to the systems, procedures, issues, and processes involved in making of payments for expenses in the public sector. In line with efficiency propositions, Premchand (1993) reveals that public expenditure management is regarded as pivotal to economic policy making in many countries on account of renewed need for having responsible, responsive and effective government that works better and costs less. Similarly, Campos (2001) also provides that public expenditure management relates to allocation and use of financial resources responsively, efficiently and effectively. According to Allen and Tomassi (2001), sustainable healthy financial position in the public sector is hinged upon good institutional arrangement during planning and budgeting for the expenditure items. Further, Shah (2007) notes that the success of governments is indicated by the PEM practices as these practices depict government policies, priorities and actions which in turn determine nature of services delivered. 
There are several suggestions aimed at enhancing efficiency in public expenditure management, some of which are in alignment with the philosophy of equity which Scott (2016) study was premised on. For example, Broback and Sjolander (2002) indicate that, the state expenditure should improve the financial situation of the poor and generate economic growth. This requires clear statements in government policy which indicates that, state expenditure will be targeted at areas which have a direct or indirect impact on the poor and foster greater economic efficiency and improved distribution of incomes.

Other discussions seem to suggest that public expenditure management should place emphasis on decentralization. For example, Cuadrado-Ballesteros (2014) argues that fiscal decentralisation enables local governments to play a major role in poverty reduction by ensuring a more effective and accountable local infrastructure and service delivery, and improve the dialogue between the state, citizens and their communities. Further, Regmi, Naidoo, Pilkington and Greer (2009) have noted that, such expenditure makes public investment in local governments more progressive and responsive to the people. The World Bank has suggested a new shift in public expenditure management to give preference to human capital development as measured through the Human Capital Index (HCI). The World Bank contended that human capital spurs inclusive economic growth, but in poor African countries, investing in health and education has not gotten the attention it deserves (Kim, 2018).

In ensuring efficiency in public expenditure, DFID (2001) clarifies that public expenditure management should seek to deliver three key objectives namely: maintain fiscal discipline, promote strategic priorities and deliver value for money. In maintaining fiscal discipline, effort should be made to keep spending within limits and debt within levels that are not prohibitively expensive to service. This should be combined with creating the ability to raise revenue. Strategic priorities should be promoted by allocating and spending resources in those areas that make the greatest contribution to the government's objectives, in line with the allocative efficiency framework (Scott, 2016). Delivering value for money entails efficient and effective use of resources in the implementation of strategic priorities. However, DFID (2001) notes that while the three objectives are interdependent and mutually reinforcing, there are instances when methods chosen to pursue fiscal discipline could undermine the achievement of strategic priorities and value for money.

Broback and Sjolander (2002) also offer that, public funds could normally be disbursed centrally from the bank account to the State or Ministry budget for expenditure purposes specified in the budget. On the other hand, funds could also be disbursed directly to the provinces and districts for expenditure. In releasing funds, agencies could receive a portion in advance, after which the agencies must requisition money when they can show evidence of how they used the money earlier received. On the other hand, DFID (2001) suggests that, the most important concern for disbursement is whether when the funds get to the payment agency, the funds received would be applied for the purposes intended in the budget, and whether this would be done in a timely manner. This paper emphasized that the system of government disbursement in many developing countries is weak, and that, it could be difficult to guarantee that money will reach the intended centres, within reasonable time and 
be used in the manner intended. The paper also was in the position that good practice assumes that government and the Ministry of Finance should be aware of all funds available for financing public expenditure, and that as long as the funds are not known to the Ministry of Finance, it is difficult to present good final accounts for government to indicate actual funds used for expenditure.

In Africa, in order to improve efficiency in Public expenditure management practices, there have been various reform programs in Public expenditure management, often entangled with reforms of the entire Public Financial Management. These reform programs in many African Countries including Ghana, Nigeria, South Africa and Kenya involved package of policy measures that included: Medium Term Expenditure Framework (MTEF), Performance Based Budgeting (PBB), Financial Management Information System (FMIS) and Cash Management components of public expenditure management (Scott, 2016).

In the case of Ghana, among various PFM reforms, there have been specific reforms in the areas of Budget and Public Expenditure Management System (BPEMS) from2003-2007 which was re-launched into the Government Integrated Financial Management System (GIFMIS) (Adzroe, 2015). With regard to expenditure trends of District Assemblies in Ghana; Osei-Akoto, Osie, Quarmine and Adiah (2007) found that, the total amount expensed by District Assemblies in Ghana constituted 6.5\% of national expenditure, and about $1.8 \%$ of GDP in 2004. A comparison of recurrent expenditure and capital (development) expenditure for the period between 1994 to 2002 indicated that recurrent expenditures were mainly higher than capital expenditures for all the Districts. Osei-Akoto et al. (2007) further observed that the more rural the district, the higher the levels of average capital expenditures. Capital (development) expenditure incurred by the District Assemblies could be categorized into social (including health, education, water and sanitation), self-help projects, sub district structures such as dispensaries and micro projects such as water piping.

\section{Problem Analysis}

Highlighting on some of the challenges of Ghana's public expenditure management, World Bank (2017) reveals that, while expenditures have grown rapidly over the last four years, public revenues have remained essentially unchanged as a share of the GDP. Further, Ghana's expenditure levels in some core essential areas such as public health budget and human capital stock is modest as compared to the standards of other lower-middle-income countries. As a result, Ghana's health indicators lag well behind those of most of its peers. At the District Assembly level, Osei-Akoto et al. (2007) reveal that despite significant progress made in reforming the public expenditure management practices, weaknesses in the implementation of the Medium-Term Expenditure Framework (MTEF) continue to make assessment of the gains in efficiency and effectiveness of government programs quite difficult.

DFID (2001) had stressed on the need for public expenditure to interrelate with the budget. Scott (2016) also revealed that public expenditure and the other components of PFM exist as a system. However, Oduro (2003) and Roberts (2003) argued that, the various components of public financial management practices in Ghana do not meet the rules of interrelatedness 
amongst themselves and in relation to service delivery. For example, World Bank (2017) had commented on the lack of relatedness of expenditure and revenue outputs in Ghana. This paper thus inferred that when there is lack of interrelatedness of expenditure with the other aspect of PFM, such as the budget, the revenue, and even the accounting practices, various challenges including Allocative inefficiencies could emerge.

Despite the several reforms in public financial management in Ghana, with many indicators premised on the basis of the New Public Management theory, there have been challenges in the adoption of such private sector indicators. For example, Adzroe (2015) cites weak expenditure monitoring and control, and mentions further that, the allocation of resources for expenditure in strategic priorities is undermined by the fragmented nature of the budget and lack of an effective monitoring and evaluation mechanisms.

Collins and Khan (2004) discussed challenges posed by information asymmetry and reveal how information asymmetry creates difficult decision-making environment. In the case of the public expenditure management practices of DAs in Ghana, World Bank (2005) indicates that, information on central government allocations to DAs becomes available to the DAs with significant delays, and for some, information on transfers does not get to them at all. Even when information on available resources is provided to the DAs, the actual transfer of funds may be substantially delayed. This situation raises issues of accumulation of arrears, and undermines the implementation of the DAs budget and expenditure management processes. Principal Agent theory also postulates that such situations could heighten various opportunistic tendencies, which could affect the expenditure management processes, and subsequently the transaction cost.

Bartle and $\mathrm{Ma}$ (2004) contend that, the transaction cost model in public expenditure management involves determination of policies, allocation of resources for the needed objectives, and the assurances that specific tasks are carried out economically, efficiently and effectively. Incidentally in the case of expenditure management practices at the national as well as the DAs in Ghana, World Bank (2017) reveals difficulties in the practices of cash planning, lack of reliability and short horizon of ceilings for expenditure commitment, lack of liquidity, several outstanding bills, and lack of regular information on cash balances. World Bank (2017) emphasizes categorically that these situations ultimately impact upon the quality of the service delivery. The World Bank (2017) further notes that, there remain substantial weaknesses in expenditure control, and that while the rules and procedures are generally clearly described in the regulatory framework and internal guidelines, they are often not adhered to.

Specific issues related to difficulties in the public expenditure management practices of District Assemblies of Ghana are contained in various Auditor General Reports. For example, a sample of the Auditor General's report for the period between 1998 and 2014 identified a number of lapses in expenditure management most of which, according to the Auditor General, had been reflected in past audit reports. Some of the lapses of expenditure management mentioned in the report include failure to issue receipts, direct disbursement from revenue sources, misapplication of funds and missing District Assemblies Common 
Fund (DACF) and Highly Indebted Poor Countries (HIPC) funds and transfers. The Auditor General had also over the years flagged misappropriation of internally generated revenue, MP's Common Fund not fully accounted for, suppression of accounting books, unsupported AIDS fund disbursements and poor accounting for salaries (Republic of Ghana, 1998a; 1998b; 2000).

Other major lapses included payment vouchers with no supporting documents, missing payment vouchers, excess expenditure without approval, unretired imprests and fraudulent and irregular payments. According to the report, each of these lapses entailed losses of several millions of Ghanaian Cedis. Findings from the Auditor-General's report on the public accounts of Ghana (Ministries, Departments and other Agencies), for the year ended 31st December, 2011 were similar to those of the previous years (Republic of Ghana, 2011). Similarly, in the report of the Auditor-General on the management and utilization of District Assemblies Common Fund (DACF) and other statutory funds for the year ended 31st December 2013, the Auditor General concluded that the increased and widespread instances of mismanagement of the finances and resources of the Assemblies were indicative that the admonitions and recommendations in previous reports, had not been significantly implemented (Republic of Ghana, 2014).

Despite the benefits associated with a clear understanding of the link between public expenditure management practices and service delivery in decentralised units, efficient public expenditure management practices seem elusive. Various observations including those by Ahmad and Brosio (2009), Essuman and Akyeampong (2011) as well as Inkoom (2011) seem to point out that after more than two decades since the adoption of decentralisation in Ghana, there are valid concerns which need continuous robust theoretical and empirical analysis. It was from the perspective of these prevailing issues that this paper set out to investigate the effect of public expenditure management practices on service delivery in the public sector entities, in the context of Ghana's District Assemblies.

\section{Literature Review}

In line with the transaction cost theory, North (1990) poses that, transaction cost is involved in defining expenditure policy because policy is essentially an expenditure contract between elected officials, the body which is charged with the mandate to guide budgeting process, and the spending agencies. Similar to the framework of the transaction cost, Premchand (1993) identifies public expenditure management as a three-stage administrative process entailing determination of policies, objectives and resources needed, the allocation of resources needed for those objectives, and the assurance that specific tasks are carried out economically, efficiently and effectively. Despite the seemingly common values of public expenditure management, Campos and Pradhan (1996) argue that, the practices of public expenditure management vary from one country to another.

Scott (2016) adapting from various authors (including Andersen \& Isaksen, 2002; Broback \& Sjolander, 2002; Ojo, 2009; Simson, Sharma \& Aziz, 2011) concurs with the systems theory that public expenditure management practices is one of the six key components of Public Financial Management. The six components identified are: budgeting, revenue mobilisation, 
public expenditure management, financial reporting, auditing and financial regulations. Broback and Sjolander (2002) argue that these PFM components are interrelated and exist as a system. Andersen and Isaksen (2002) assert that all the identified components are important in a development context and must continuously be improved in order for government to implement its development objectives. Simson et al. (2011) support the Broback and Sjolander (2002) argument and further note that, improvement of one component is dependent on, and conditioned on the state of other components if development objectives are to be met.

Based on the new public management and allocative efficiency perspectives, Schick (1998) has noted that the basic goals of public expenditure management are to accomplish macro financial discipline, strategic priorities in resource allocation, and functional application of resources. Allen and Tomassi (2001) argue that, mere fiscal discipline in the presence of arbitrary resource allocation and inefficient operations are inherently unsustainable for effective public expenditure management. In contrast, Heimans (2002) holds that without fiscal discipline, it is impossible to achieve effective prioritisation and implementation of policies and programs. Heimans reiterates again the need to improve the internal expenditure management systems in order to sustain efficiency. Lienert (2003) supports Schick, and argues that all the three goals are in strong interaction and are complementary and interdependent. This is in sync with the assumptions of the systems theory.

Discussing the principal agent theory, Martin in Khan and Hildreth (2004) raises the issues of "incomplete contract" and "agent opportunism". Incomplete contract, according to Martin, refers to a contract which lacks sufficient precision and specificities to cover all its service delivery contingencies. Agent opportunism refers to a situation that contractors (agents) sometimes pursue their own interest rather than the interest of the government (principal). The relevance of incomplete contract and agent opportunism to public expenditure management lies in Martin's assertion that; the greater the degree of completeness of a contract, the greater the degree of precision that is achieved in the service delivery and the lower the transaction cost. In the case of agent opportunism, the issue is that where there is agent opportunism, contractors tend to provide lower-quality services, in order to increase their profit margins.

\section{Empirical Review}

The empirical literature reveals some peculiar features about public expenditure management in decentralised authorities and posts mixed results on the link between expenditure and services in the decentralized government units. For example, Faguet (1999) found that decentralisation efforts in Bolivia increased capital expenditure in socially oriented sectors, such as education, urban development, water and sanitation, and health care thus improvements in accessibility and quality of services delivered in these sectors. Further, World Bank (2003) found that fiscal decentralisation in Spain is a critical determinant of the share of the public budget devoted to capital expenditures. In another study, Osei-Akoto et al. (2007) compared public expenditure trends in urban as against rural districts in Ghana, and observed that, the more rural the district, the higher the levels of average capital expenditures 
due to size of bureaucracies, number of employees, and size of government at that level relative to the level of spending for infrastructural projects.

Further, Herrala and Haapasalo (2012) have contended that local governments often lack good public expenditure management systems to assist their tax and budget choices due to the general belief that firms can deliver goods and services more efficiently and at lower cost than the public sector, when operating in competitive markets. Further empirical evidence relevant to the link between public expenditure management and service delivery is by Uchimura (2012). The study investigated the impact of local health expenditures on health service in Philippines municipalities. The study found that the higher health spending by the municipalities lead to provision of better public services in the form of immunization rates as a result of construction of more health stations and employment of more nurses. The findings by Uchimura (2012) contradict Otieno, Odundo and Rambo (2014) deduction that the disbursement and utilization of resources to local authorities in Kenya for over ten years had not contributed to improved delivery of essential services.

\section{Conceptual Framework}

Based on the foregoing discussions, a conceptual framework for public expenditure management practices and service delivery (Figure 1) was developed to show the link between public expenditure management practices and service delivery as applicable for the District Assemblies of Ghana. The paper held that public expenditure management practices as indicated by policies, procedures, capital expenditure, recurrent expenditures and expenditure priorities, have an effect on the services delivered by the district assemblies (Scott, 2016). The indicators for service delivery are borrowed from Scott (2018), who identified services availability, quality of services, cost of services and citizen satisfaction as reliable measures of service delivery. In line with the systems framework, this study conceptualized public expenditure management practices as the independent variable while service delivery was the dependent variable.

The systems theory helped in understanding the interactions and relationships between public expenditure management practices, and service delivery in DAs. These systemic interactions are indicated by arrows from the systems theory to the other theories (new public management theory, transaction cost, principal agency and allocative efficiency). Several authors (including Lee, 2012; Herrala \& Haapasalo, 2012; Hwang \& Choi, 2012; Klievink \& Janssen, 2009; Osborne, 2009) have noted that, the numerous models being used in explaining and understanding public financial management and service delivery are dynamic and call for innovations for improving service delivery to the citizens. The conceptual framework of this study is a contribution towards this end. 


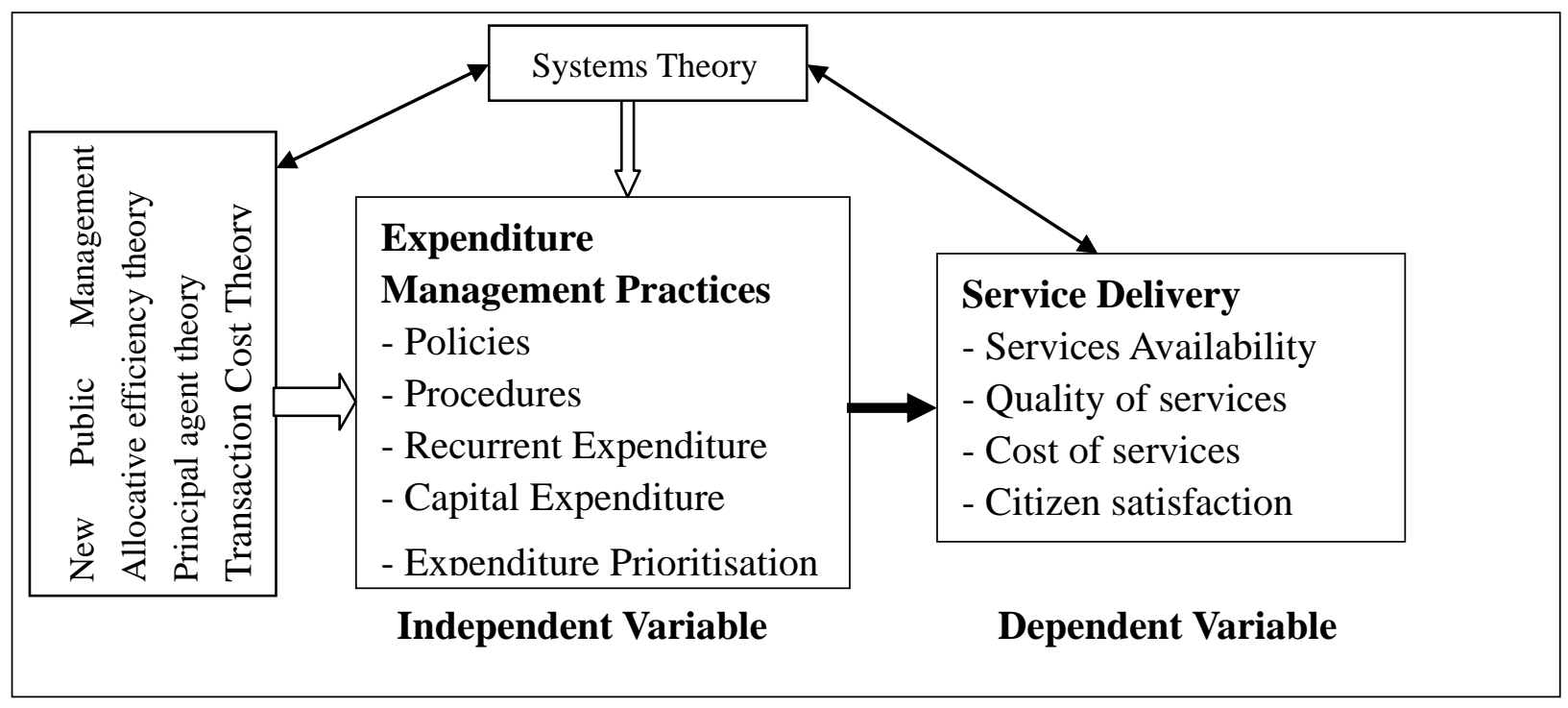

Figure 1. Conceptual Framework for Public Expenditure Management Practices and Service Delivery

Source: Author based on various views from literature.

\section{Methodology}

This study was guided by the pragmatic research philosophy, using the mixed method research design where both quantitative and qualitative tools were applied. These tools enabled the study test a research hypothesis and provide deeper explanations into public expenditure management practices and their effect on service delivery. Questionnaire was used to gather quantitative data, while qualitative data were gathered using interviews and focus group discussions. The quantitative items on the research questionnaires were further probed through the interviews, key informants and focus group discussions to answer the question 'how'. According to Mangan, Lalwani and Gardner (2004), methodological triangulation and using mixed methodologies increasingly provide multidimensional insights into diverse research problems. The study applied the correlational design to depict the accurate linkage between expenditure management practices to service delivery in the DAs of Ghana.

The study population was the 170 DAs that were in existence in Ghana as at 2008 with a population of 23.11 million. Multistage sampling was used to pick respondents. First, 20\% proportionate sampling was applied to select 34 DAs from the ten geographical regions of Ghana. The DAs selected were representative of the diverse characteristics of the DAs in Ghana based on various factors such as; location, rural-urban, and poverty levels. From each of the 34 DAs, two DA officials from each of the nine key departments in the DA were selected yielding a total of 612 respondents.

Convenience sampling was applied to select 30 citizens from each of the 34 sampled DAs based on the Central Limit Theorem (Kwak \& Kim, 2017), which brought the total number of citizen respondents to 1,020 . Purposive sampling was used to select 28 participants as key 
informants. These informants were comprised of officers from the national and regional levels whose work was directly related to public expenditure management and service delivery of the DAs. Lastly, purposive sampling was used to select ten participants for each of the two focus group discussion which were based in Tema and Tamale. A total of 963 out of 1020 questionnaires from citizens and 443 out of 612 from the DA officials were retrieved. Descriptive statistics and regression analysis tools from Statistical Product and Service Solutions (SPSS) version 21 were used to analyse the data. The quantitative data was analysed using descriptive statistics - percentages, mean scores, standard deviation, correlation and multiple regression technique; while qualitative data were analysed using thematic summary analyses.

\section{Data Analyses and Discussions}

The objective of this study was to find out the effect of public expenditure management practices on service delivery. Issues discussed under this section include the following:

a) Public expenditure management policies in the District Assemblies

b) Efficiency of expenditure management practices

c) Extent to which expenditure management practices influence service delivery

d) Link between expenditure management practices and service delivery

e) Hypothesis results on effect of expenditure management practices on service delivery.

\subsection{Expenditure Management Polices in the District Assemblies}

The study first sought information on whether there were policies guiding the expenditure management practices within the DAs. The results revealed that majority (86\%) of the DA officers indicated that there were laid down procedures and policies to guide the expenditure management practices in the District Assemblies. The results reflected the situation on the ground as there were several frameworks, policies and regulations to guide expenditure in the districts. The researcher made checks in several offices and found that there were various policies and guidelines on expenditure management in the DA offices. Some records were located with the DA top officials, and the registries where office records were kept.

As depicted in the conceptual framework, one important requirement for effectiveness in expenditure management practices was the presence of procedures and policies on these practices. These would be important in enhancing service delivery through efficient expenditure controls. This finding is in line with the position by Broback and Sjolander (2002) who indicated that at the policy level, public expenditure should aim at improving the wellbeing of the citizens and generate economic growth in line with the equity proposition. DFID (2001) also advises that public expenditure decisions should be made in the context of the annual budget process, which is influenced by the wider policy process and also by the legal framework of government. The study also found that other policies and regulations on public expenditure are received from the Ministry of Local Government, the Controller and Accounts General Department (CAGD) and the Ministry of Finance (MoF). This reinforced 
Osei-Akoto et al. (2007) observations on the existing laws and regulations pertaining to DAs in Ghana which include the Financial Administration Act, 2003 (Act 654); the Internal Audit Act, 2003 (Act 658) and the Procurement Act, 2003 (Act 663) which guide public expenditure management practices.

The study further sought views from the DA officials on whether the expenditure management policies were uniform across the DAs. Study results indicated that out of those who reported that there were laid down procedures and policies to guide the expenditure management practices, 85 percent indicated that the policies were uniform to all District Assemblies. This finding is contrary to the results by Herrala and Haapasalo (2012) who established that local governments often lacked standardized public expenditure management policies, and that jeopardize the effectiveness of the DAs' payments procedures.

The key informants in describing the policies guiding the expenditure management practices stated that the DA officials required that a memo must be raised to the District Coordinating Director (DCD), and then forwarded to the District Finance Officer (DFO). The DFO confirms revenue availability and forwards the memo to District Budget Office (DBO) who prepares a warrant for the necessary payment. The key informants further indicated that after approval of expenditure, a warrant is generated by the budget section officials. This warrant is then forwarded to the internal audit for checks and finally taken to the finance department for payment and processing. The key informants noted that these processes and procedures were cumbersome.

\subsection{Efficiency of Expenditure Management Practices}

The study then asked the DA officials to rate the efficiency of expenditure management practices in the district assemblies. The measurement was on a four-point rating scale (1Very Inefficient, 2-Inefficient, 3-Efficient and 4-Very Efficient) which were interpreted using percentages. The results are presented in Figure 2. Majority $(65.3 \%)$ of the DA officials rated the existing expenditure management practices at the District Assemblies as efficient and very efficient. However, 34.7 percent indicated that the practices were inefficient and very inefficient.

\section{Efficiency of the DAs Expenditure Management Practices}

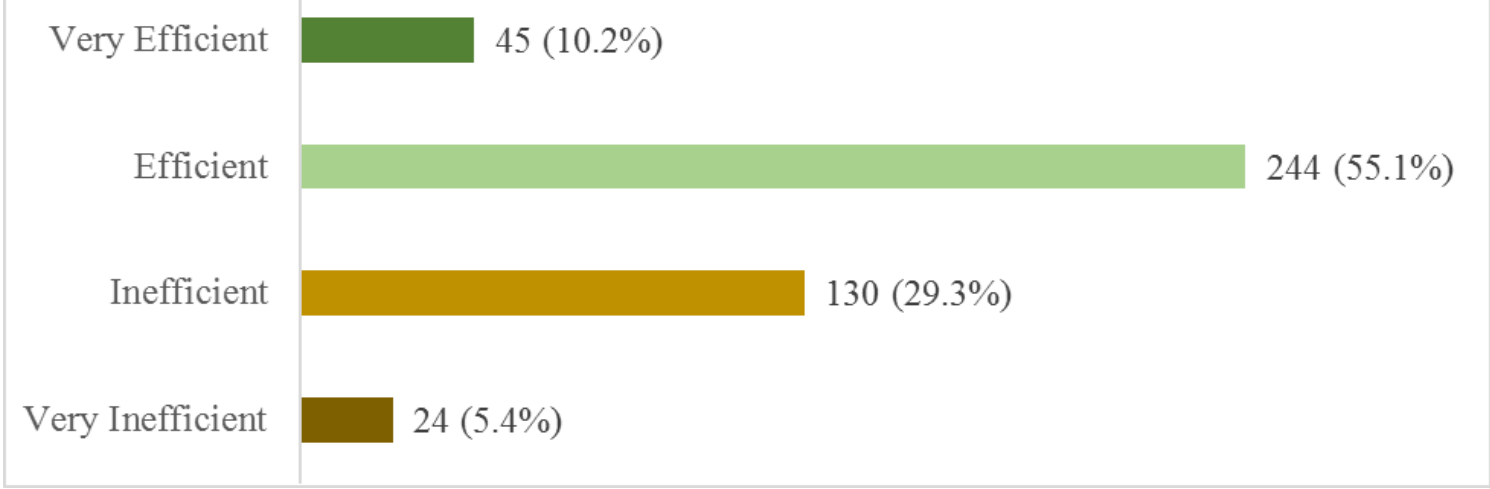

Figure 2. Rating the Expenditure Management Practices 
Source: Scott, Field Data, 2014

Information regarding the nature of expenditure management practices in the DAs was also sought from key informant interviews. The key informants noted that the recurrent expenditure of District Assemblies is almost always higher than that of development expenditure. One informant clearly indicated that: "This pattern made it difficult for the assemblies to effectively manage financial resources intended for projects aimed at delivering services to the public."

This observation by key informants goes to support the findings in the Osei-Akoto et al (2007) study, which the recurrent and capital expenditures were compared across all districts in Ghana. The results show that, for most of the period (between 1994 and 1998; and from 2001 to 2002), recurrent expenditures were higher than capital expenditures for all the districts analysed. The key informants further indicated that release of funds from central government was also always delayed. Inspection of some DACF trail records in some of the assemblies by the researcher confirmed this assertion. For example, the release for the last quarter of year 2010 arrived in some of the districts in April 2011.

\subsection{Link between Expenditure Management Practices and Service Delivery}

Further, the study probed the link between expenditure management practices and service delivery using statements on a likert scale of 1 to 5 (1- strongly disagree to 5 - strongly agree) which were interpreted using percentages, and the results are presented in Table 1.

Table 1. Expenditure Management Practices and Service Delivery in Percentages

\begin{tabular}{l|l|l|l|l|l}
\hline Expenditure Management practices & 1 & 2 & 3 & 4 & 5 \\
\hline Employees are paid their wages and salaries in time & 13.1 & 17.4 & 11.3 & 27.4 & 30.8 \\
\hline $\begin{array}{l}\text { Contractors and suppliers are paid in time enabling smooth } \\
\text { provision of services }\end{array}$ & 20.4 & 26.5 & 12.9 & 24.9 & 15.4 \\
\hline $\begin{array}{l}\text { Expenditure and payments processes are not complex and } \\
\text { tedious }\end{array}$ & 16.7 & 17.2 & 18.1 & 21.3 & 26.7 \\
\hline $\begin{array}{l}\text { Verifications are made on work completion stages; quality } \\
\text { of goods, service and projects before payments are } \\
\text { effected }\end{array}$ & 6.6 & 9.3 & 10.6 & 24.0 & 49.6 \\
\hline $\begin{array}{l}\text { Some expenditures are given priority over other } \\
\text { expenditures during payments }\end{array}$ & 5.4 & 3.4 & 11.8 & 27.4 & 52.0 \\
\hline
\end{tabular}

Source: Scott, Field Data, 2014

The results in Table 1 indicate that 79.4 percent of the DA officials agreed or strongly agreed that some expenditures were prioritized over others. This relates with Heimans' (2002) observation that effective prioritization and implementation of policy priorities were key to fiscal discipline. Further results indicated that 73.6 percent agreed or strongly agreed that verifications are made regarding work completion stages; quality of goods, service and projects before payments were effected. This result is in line with the findings by Premchand (1993) which identified verification as an important activity in payments for public goods and 
services to ensure that only legitimate bills were paid. Similarly, 58.1 percent of the DA respondents agreed or strongly agreed that salaries and wages were paid on time.

Means scores and standard deviations (S.D) were applied to conduct further analysis on the link between expenditure management practices and service delivery. Results presented in Table 2 indicate that the DA officials agreed that work completion and quality of goods, service and works was verified before payments were made, as shown by a mean score of 3.89. The respondents further agreed that some expenditures were prioritized over others (4.06). However, the respondents were neutral (neither agreed nor disagreed) on whether salaries and wages were paid in time (3.28); whether contractors and suppliers were paid in time enabling smooth provision of services and on whether expenditure and payments processes were not complex and tedious (3.02). As noted in the conceptual framework, the DAs had important expenditure management practices including prioritization and verification of payments.

Table 2. Expenditure Management Practices and Service Delivery- Means and S.D

\begin{tabular}{l|l|l}
\hline Expenditure Management Practices & Mean & S. D \\
\hline Employees are paid their wages and salaries in time & 3.28 & 1.39855 \\
\hline $\begin{array}{l}\text { Contractors and suppliers are paid in time enabling smooth } \\
\text { provision of services }\end{array}$ & 2.64 & 1.26023 \\
\hline Expenditure and payments processes are not complex and tedious & 3.02 & 1.37377 \\
\hline $\begin{array}{l}\text { Work completion and quality of goods, service and works are } \\
\text { verified before payments are made }\end{array}$ & 3.89 & 1.27399 \\
\hline $\begin{array}{l}\text { Some expenditures are given priority over other expenditures } \\
\text { during payment }\end{array}$ & 4.06 & 1.13932 \\
\hline
\end{tabular}

Source: Scott, Field Data, 2014

\subsection{Extent to Which Expenditure Management Practices Influence Service Delivery}

The study also sought to understand the extent to which the overall expenditure management practices influence service delivery. Five-point rating scale was used to measure the extent (1-Very Low Extent, 2-Low Extent, 3-Moderate Extent, 4-High Extent and 5-Very High Extent) and interpreted using percentages. Results presented in Figure 3 revealed that half (50.2\%) of the respondents indicated that expenditure management practices influence service delivery to a high and very high extent. Thirty one percent $(32 \%)$ of the DA respondents indicated that the expenditure management practices influence service delivery to a moderate extent while 17.8 percent indicated that expenditure management practices influenced service delivery to a very low and low extent. 


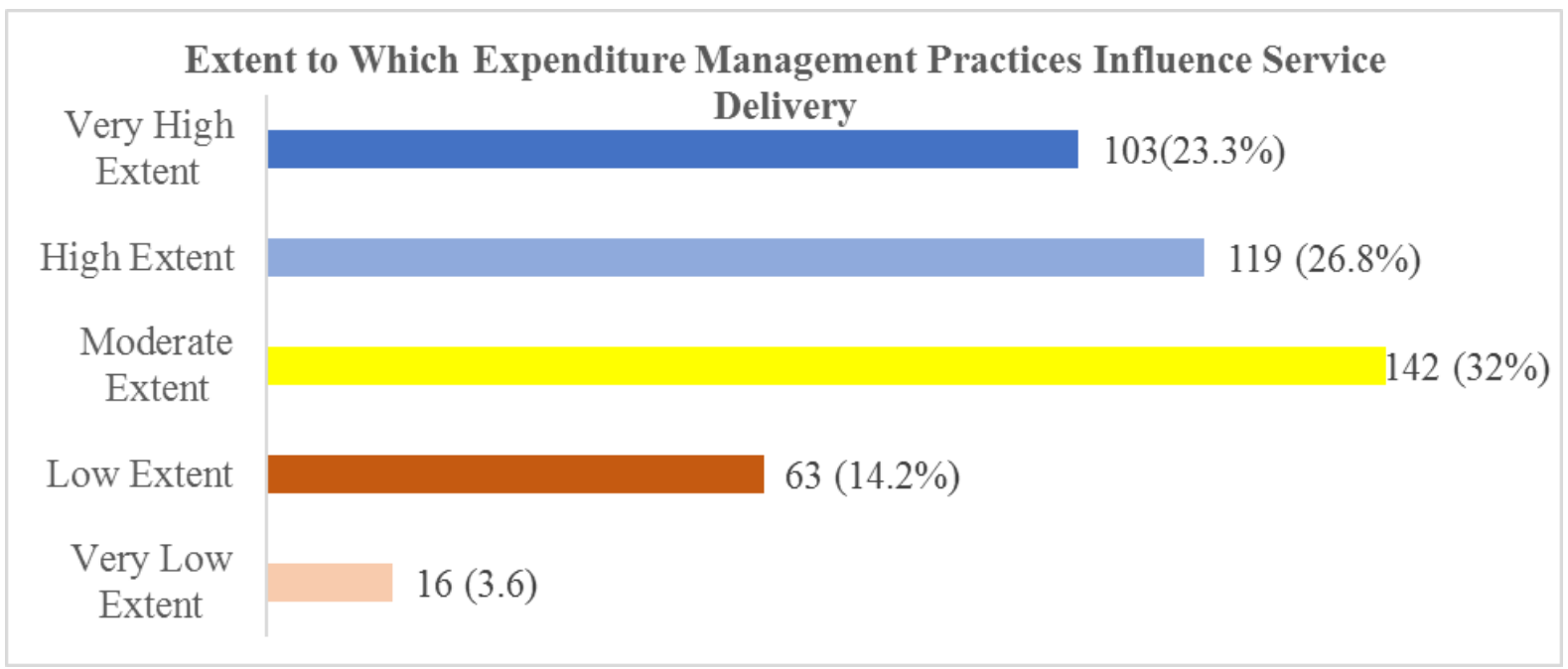

Figure 3. Extent to Which Expenditure Management Practices Influence Service Delivery

Source: Scott, Field Data, 2014

The results in Figure 3 can be explained by the findings by Uchimura, 2012 as well as Cuadrado-Ballesteros (2014) who showed that expenditure management practices influence service delivery in decentralized units to varied extent. However, the findings contradict Otieno et al. (2014) who found no effect of decentralized expenditure on service delivery by local authorities. The two focus group discussions participants as well as the key informants attributed the nature of the extent of influence of expenditure management practices on service delivery as depicted in Figure 3 to the challenges in the public expenditure management practices. Challenges noted in the focus group discussion in Tema included; expenditure items of the assemblies fraught with suspicious documentation, unnecessary bureaucracies, lack of transparency and corruption. One focus group participant in Tema noted that, "payments of outstanding debts often delayed as a result of late release of funds from government." A technical director at DACF reiterated that the delays in release of funds by central government constrained the operations of the DAs in offering services.

It emerged from the focus group discussion in Tamale that despite a lot of time and effort being spent to prepare well planned budgets to guide expenditures, the final expenditures of the assembly did not follow the budgeted estimates. This observation indicates that the budgeted expenditures by the DAs were rarely adhered to. Discussing such challenges in line with aspects of the transaction cost theory, Shah (2007) observed the non-credible commitments of elected officials in the budgeting processes in developing countries. Shah mentioned that in such environment, budget appropriations to agencies were not necessarily available from the Ministry of Finance, and expenditure contracts were not enforceable.

A budget officer reported during an interview that there were variances between the budgeted and the actual expenditures on varied votes in the DAs. These variances meant that some of the expenditure votes did not receive the necessary attention and funding as stated in the budgets thus making service delivery to suffer in such areas. The focus group participants in Tema noted that that the Office of the District Assemblies' Common Fund often made some 
deductions from the DACF funds before the funds were released to the Assemblies. Records at some of the Assemblies, including Twifu/Heman/Lower Denkyirah District Assembly (THLDA) revealed similar concerns. Diamond (2000) revealed that in the expenditure contract between the elected officials and the spending agencies both categories of officials may behave opportunistically.

\subsection{Hypothesis Testing for Effects of Expenditure Management Practices on Service Delivery}

The study tested the hypothesis that expenditure management practices of the district assemblies in Ghana have a significant influence on service delivery as conceptualized in the conceptual framework. This was done through multiple regression analysis results (Tables $3-5)$.

Table 3. Model Summary

\begin{tabular}{c|c|c|c}
\hline $\mathrm{R}$ & R Square & Adjusted R Square & $\begin{array}{c}\text { Std. Error of the } \\
\text { Estimate }\end{array}$ \\
\hline .404 & .163 & .153 & 9.32048 \\
\hline
\end{tabular}

a. Predictors: (Constant), expenditure management practices

The results provided in Table 3 reveal that expenditure management practices explained around 16.3 percent of the variation in service delivery ( $\mathrm{r}$ squared). This implies that 83.7 percent of the variation in service delivery in the surveyed DAs can be explained by other factors that were not incorporated in the model. This is justifiable since service delivery by government entities such as DAs is affected by host of factors. For instance, Doh (2017) found that staff quality in selected District Assemblies in Ghana had serious implication for service delivery while Gaitho, Ogutu, Awino and Kitiabi (2018) found that strategic planning and ethical practices affected service delivery in county governments in Kenya.

Table 4. Analysis of Variance

\begin{tabular}{l|r|r|r|r|r}
\hline $\begin{array}{l}\text { Source of } \\
\text { Variance }\end{array}$ & $\begin{array}{c}\text { Sum of } \\
\text { Squares }\end{array}$ & df & Mean Square & F & \multicolumn{2}{c}{ Sig. } \\
\hline Regression & 7381.216 & 5 & 1476.243 & 16.993 & .000 \\
\hline Residual & 37875.933 & 436 & 86.871 & & \\
\hline Total & 45257.149 & 441 & & & \\
\hline
\end{tabular}

a. Dependent Variable: Service delivery

a. Predictors: (Constant), Expenditure management practices

Table 4 present the results of the analysis of variance. The findings indicate that the model was statistically significant $(\mathrm{F}=16.993 ; \mathrm{p}<0.05)$. This implies that the model can provide predictive ability when expenditure management practices are used to explain service delivery. Moreover, the results indicate that expenditure management factors in the Ghanaian DAs can reliably explain the nature of services offered to the citizens. 
Table 5. Effects of Public Expenditure Management Practices on Service Delivery

\begin{tabular}{|c|c|c|c|c|c|}
\hline \multirow[t]{2}{*}{$\begin{array}{l}\text { Public } \\
\text { Aspects }\end{array}$} & \multicolumn{2}{|c|}{$\begin{array}{l}\text { Unstandardized } \\
\text { Coefficients }\end{array}$} & \multirow{2}{*}{$\begin{array}{l}\text { Standardized } \\
\text { Coefficients } \\
\text { Beta }\end{array}$} & \multirow[t]{2}{*}{$\mathrm{t}$} & \multirow[t]{2}{*}{ Sig. } \\
\hline & B & $\begin{array}{l}\text { Std. } \\
\text { Error }\end{array}$ & & & \\
\hline (Constant) & .361 & .510 & & .708 & .487 \\
\hline Policies & .082 & .020 & .139 & 4.100 & .000 \\
\hline Procedures & .510 & .069 & 1.460 & 7.376 & .000 \\
\hline Recurrent Expenditure & .383 & .072 & 1.104 & 5.293 & .000 \\
\hline Capital Expenditure & .117 & .035 & .368 & 3.337 & .001 \\
\hline Expenditure Prioritisation & .056 & .026 & .195 & 2.178 & .030 \\
\hline
\end{tabular}

Table 5 regression results indicate that expenditure policies $(\beta=.082, \mathrm{p}=.000)$, procedures $(\beta=.510, p=.000)$, recurrent expenditure $(\beta=.383, p=.000)$, capital expenditure $(\beta=.117$, $\mathrm{p}=.001)$ and expenditure prioritisation $(\beta=.056, \mathrm{p}=.030)$ had a positive and significant influence on service delivery. This shows that the expenditure management practices in the District Assemblies studied influenced availability, quality of services offered as well citizen satisfaction. The null hypothesis that expenditure management practices had no significant effect on service delivery was therefore rejected.

The study findings show that when expenditures are well planned, prioritized and efficiently managed, their effect on service delivery is notable. The study noted that high expenditure does not necessarily lead to improved services as this is mainly determined by how the expenditure is managed. This situation was observed in this study as expenditures were prompt, prioritized and efficient. The study's conceptual framework had depicted that for public expenditure management practices to have an effect on service delivery, they required key aspects including efficiency, prioritization and adherence to laid down policies. The districts surveyed seemed to have adhered to these key qualities to a great extent despite many shortcomings and challenges observed in the study.

The key informants acknowledged that expenditure management practices have a great influence on service delivery because key activities, including payment for assembly members' meetings could be frustrated due to lack of funds. The focus group participants at Tamale noted that with a large proportion of funds going to recurrent expenditure (salaries and allowances), little was left for service delivery activities. These findings reinforce the observations from a study by Uchimura (2012) who found that increased local health expenditures had positive impact on health services by Philippines municipalities.

\section{Conclusions and Policy Recommendations}

The study provides that public expenditure management practices of the district assemblies in Ghana have a significant influence on service delivery. There were laid down procedures, several frameworks, regulations and policies to guide the expenditure management practices in the District Assemblies. There were also indications that some expenditures were prioritized over others. While DA officials rated the existing expenditure management 
practices at the District Assemblies as efficient and very efficient, the key informants noted that the recurrent expenditure of District Assemblies was almost always higher than that of development expenditure. This pattern according to the informants, made it difficult for the Assemblies to effectively manage financial resources intended for projects aimed at delivering services to the public. Several difficulties were also identified with expenditures at the DA level. The focus group and Auditor General noted that many expenditure items of the assemblies were fraught with suspicion, unnecessary bureaucracies, lack of transparency, non-adherence to budget guidelines, errors and corruption. Delays in funds releases by central government also constrained the operations and payments for services.

The study recommends that, at the DA level, the DAs should prioritize and give preference to expenditures in key service delivery areas such as; those that enhance poverty reduction, improve on Human Capital index such as education and health, and those that strengthen innovation practices in critical areas including infrastructure, agriculture, and financial transactions.

DAs should strengthen electronic, automation and appropriate technologies for better expenditure management and service delivery. Automation systems such as electronic bank transfers, payments with electronic cards, and integration of mobile payment platforms in expenditure services could reduce errors, minimize falsifications, streamline bureaucracy and enhance expenditure management while improving service delivery. In liaison with the national government, DAs and Ministry Of finance should strengthen the DAs in the integration, operationalization and strengthening of technologies such as the Integrated Financial Management Information Systems (IFMIS) through support for budgetary allocation and staff capacity development.

DAs should improve the capacity of all category of staff who are involved with expenditure management, and even staff of other sections such as the accounting and internal auditing teams so that they can effectively utilize innovations and appropriate technologies to manage and monitor expenditure operations in the DAs.

The Assemblies should also form, operationalize and strengthen budget/expenditure management committees. A committee chaired by top officials such as the District Budget/Planning Officer, could be set up to discuss and find solutions to some of the deficiencies in the expenditure management of the DAs

At the national level, the study recommends that, the Ministry of Local Government, the Head of Local Government Service Secretariat (LGSS) and other institutions such as the District Assemblies Common Fund (DACF) should ensure efficient and timely transfers of funds to the DAs in order to enhance prompt payment to contractors on projects and other services as this has profound effect on the economy. The national government should amend, review and consolidate existing Public Expenditure management laws to ensure stiffer penalties and enforcement of sanctions on those involved in malpractices in public expenditure management practices. There should be persistent and critical effort to implement recommendations of the Auditor General's report on DA expenditures practices 
Civil society should strive to educate the public/citizens and create awareness on the various expenditure management systems of the DAs, and how the expenditures relate to service delivery. Public awareness should be enhanced on the relationship between local taxes that citizens pay and the expenditure practices of the DAs. This will improve the level of accountability between the citizens and the DAs. Such awareness could be facilitated through broad stakeholders' input and feedback which can be achieved by integrating and enhancing the use of innovative communication tools such as DAs websites, emails, Facebook, Twitter and WhatsApp to supplement the stakeholders' meetings, workshops and conferences. This could help the DAs to enhance trust, transparency, and accountability among the stakeholders due to the increased citizen participation and scrutiny of the DAs' expenditures. As emphasized by Nica and Potcovaru (2015), social media tools offer a great opportunity for optimizing public participation in service delivery processes.

\section{References}

Abba, M., \& Kakanda, M. M. (2017). Moderating Effect of Internal Control System on the Relationship Between Government Revenue and Expenditure. Asian Economic and Financial Review, 7(4), 381-392. https://doi.org/10.18488/journal.aefr/2017.7.4/102.4.381.392

Adams, R. A. (2006). Public sector accounting and finance: Made simple (Rev. ed.). Lagos, Nigeria: Corporate Publishers Ventures.

Adejoh, E., \& Sule, J. G. (2013). Revenue generation: Its impact on government developmental effort: a study of selected local council in Kogi East Senatorial District. Global Journal of Management and Business Research Administration and Management, 13(4), 17-25. Retrieved from journalofbusiness.org

Adzroe, G. (2015). An overview of PFM reforms in Ghana. Presentation by the Controller and Accountant-General at the Labadi Beach Hotel during the IFAC Round Table Discussion on IPSAS from 21st-22 ${ }^{\text {nd }}$ May 2015.

Ahmad, E., \& Brosio, G. (2009). Does decentralisation enhance service delivery and poverty reduction? Boston: Edward Elgar Publishing. https://doi.org/10.4337/9781849801850

Akrani, G. (2011). What is public expenditure? Meaning, definition. Accessed on March 2015 from https://goo.gl/E6eSfr

Allen, R., \& Tomassi, D. (Eds.). (2001). Managing public expenditure: A reference book for transition countries. Brussels: OECD Publishing. https://doi.org/10.1787/9789264192607-en

Andersen, G., \& Isaksen, J. (2002). Best practice in capacity building in public finance management in Africa. Experiences of NORAD and SIDA. Bergen, Norway: Chr. Michelsen Institute.

Bartle, J. R., \& Ma, J. (2004). Managing financial transactions efficiently: A transaction cost model of public financial management. In A. Khan \& W. B. Hildreth (Eds.), Financial Management Theory in the Public Sector (1 - 23). Westport: Praeger Publishers.

Bhatia, H. L. (2009). Public finance. New Delhi: Vikas Publishing House. 
Broback, U., \& Sjolander, S. (2002). Programme support and public finance management: A new role for bilateral donors in poverty strategy work. SIDA Studies No.6. Gothenburg: Novum Grafiska AB. Retrieved from http://goo.gl/B7zrh6

Campos, J. D., \& Pradhan, S. (1996). Evaluating public expenditure management systems: An Experimental Methodology with an Application to the Australia and New Zealand Reforms. Washington: World Bank Publications.

Campos, J. E. (2001). What is public expenditure (PEM)? Governance Brief Issue 1. N.P.: Asian Development Bank. Retrieved from http://www.adb.org

Collins, B. K., \& Khan, A. (2004). Information Asymmetry in Public Investment Management. In A. Khan \& W. B. Hildreth (Eds.), Financial Management Theory in the Public Sector (25 - 54). Westport: Praeger Publishers.

Cuadrado-Ballesteros, B. (2014). The impact of functional decentralization and externalization on local government transparency. Government Information Quarterly, 31(2), 265-277. https://doi.org/10.1016/j.giq.2013.10.012

DFiD (2001). Understanding and reforming public expenditure management. London: DFID.

Diamond, J. (2000). Public expenditure management. In Conference on Post-Election Strategy, 4, 5-7, Moscow, Russia.

Doh, D. (2017). Staff Quality and Service Delivery: Evaluating Two Ghanaian District Assemblies. IDS Bulletin, 48(2), 71-90. https://doi.org/10.19088/1968-2017.117

Essuman, A., \& Akyeampong, K. (2011). Decentralisation policy and practice in Ghana: the promise and reality of community participation in education in rural communities. Journal of Education Policy, 26(4), 513-527. https://doi.org/10.1080/02680939.2011.554999

Faguet, J. P. (1999). Does decentralization increase responsiveness to local needs? Evidence from Bolivia. The World Bank. https://doi.org/10.1596/1813-9450-2516

Gaitho, P. R., Ogutu, M., Awino, Z. B., \& Kitiabi, R. (2018). Strategic leadership and service delivery of County Governments: The Kenyan experience. International Journal of Economics, Commerce and Management [online], VI (11), 395-411. Retrieved from ijecm.co.uk/wp-content/uploads/2018/11/61129.pdf

Heimans, J. (2002). Strengthening participation in public expenditure management. OECD Development Centre Policy Briefs, No. 22. Paris: OECD Publishing. https://doi.org/10.1787/640564834060

Herrala, M. E., \& Haapasalo, H. J. O. (2012). Effect of governance models on enhancing water service delivery. International Journal of Public Sector Management, 25(5), 373-390. https://doi.org/10.1108/09513551211252396

Hwang, T., \& Choi, D. (2012). Open innovation in the public sector of leading countries. Management Decision, 50(1), 147-162. https://doi.org/10.1108/00251741211194921 
Inkoom, D. K. B. (2011). Ghana's decentralisation: Two decades and still crawling \& quest. Development, 54(3), 393-399. https://doi.org/10.1057/dev.2011.68

Kim, J. K. (2018). The Human Capital Gap Getting Governments to Invest in People. Foreign Affairs (July). Available at https://www.foreignaffairs.com/articles/2018-06-14/human-capital-gap

Klievink, B., \& Janssen, M. (2009). Realizing joined-up government - dynamic capabilities and stage models for transformation. Government Information Quarterly, 26(2), 275-284. https://doi.org/10.1016/j.giq.2008.12.007

Kwak, S. G., \& Kim, J. H. (2017). Central limit theorem: the cornerstone of modern statistics. Korean journal of anesthesiology, 70(2), 144. https://doi.org/10.4097/kjae.2017.70.2.144

Lee, R. D. (2012). Public budgeting systems. Sudbury, MA: Jones \& Bartlett Publishers.

Lienert, I. (2003). A comparison between two public expenditure management systems in Africa. Washington DC: International Monetary Fund. https://doi.org/10.5089/9781451841787.001

Mangan, J., Lalwani, C., \& Gardner, B. (2004). Combining quantitative and qualitative methodologies in logistics research. International Journal of Physical Distribution \& Logistics Management, 34 (7), 565 - 578. https://doi.org/10.1108/09600030410552258

Martin L. L. (2004). Bridging the gap between contact service delivery and public financial management: Applying theory to practice. In, Khan A. \& Hildreth W. B. (Eds.) Financial management theory in the public sector (pp.55-70). Westport, CT: Praeger Publishers.

Nica, E., \& Potcovaru, A. M. (2015). Effective m-government services and increased citizen participation: Flexible and personalized ways of interacting with public administrations. Journal of Self-Governance and Management Economics, 3(2), 92-97.

North, D. C. (1990). A transaction cost theory of politics. Journal of Theoretical Politics, 2 (4), 355-367. https://doi.org/10.1177/0951692890002004001

Oduro, K. N. (2003). Results-oriented public expenditure management: Case study of Ghana. London: Overseas Development Institute.

Ojo, O. (2009). Efficient Financial Management for Local Governments: The Nigerian Experience. Petroleum-Gas University of Ploiesti Bulletin, Economic Sciences Series, 61(2) $36-44$.

Osborne, S. P. (Ed.). (2009). The new public governance: Emerging perspectives on the theory and practice of public governance. London: Routledge. https://doi.org/10.4324/9780203861684

Osei-Akoto, R. D., Osie, W., Quarmine, G. A., \& Adia (2007). Public spending at the district level in Ghana: Ghana. Strategy Support Paper (GSSP) Background Paper No. GSSP 0008. Accra: International Food Policy Research Institute. 


\section{Macrothink}

Journal of Public Administration and Governance

ISSN 2161-7104 2019, Vol. 9, No. 2

Otieno, J. O., Odundo, P. A., \& Rambo, C. M. (2014). Influence of local authority transfer fund (LATF) on service delivery by local government authorities in Kenya. International Journal of Management and Marketing Research, 7(1), 59-72.

Premchand, A. (1993). Public expenditure management. Washington D.C.: International Monetary Fund.

Regmi, K., Naidoo, J., Pilkington, P. A., \& Greer, A. (2009). Decentralization and district health services in Nepal: understanding the views of service users and service providers. Journal of Public Health, 32(3), 406-417. https://doi.org/10.1093/pubmed/fdp116

Republic of Ghana. (1998a). Auditor General's Report 1997. Accra: Ghana Publishing Company

Republic of Ghana. (1998b). Serious Fraud Office Report 1997. Accra: Ghana Publishing Company

Republic of Ghana. (2000). Ghana, Auditor General's Report 1999. Accra: Ghana Publishing Company.

Republic of Ghana. (2011). Auditor General's Report 2010. Accra: Ghana Publishing Company.

Republic of Ghana. (2014). Auditor General's Report 2010. Accra: Ghana Publishing Company.

Roberts, J. (2003). Managing public expenditure for development results and poverty reduction. London: Overseas Development Institute (ODI).

Schick, A. (1998). A contemporary approach to public expenditure management. Washington D.C.: World Bank Institute.

Scott, G. K. (2016). Influence of public financial management practices on service delivery: a case of District Assemblies of Ghana. Unpublished PhD Thesis. University of Cape Coast, Ghana.

Scott, G. K. (2018). Accounting and Financial Reporting Practices as Tools for Service Delivery in The Public Service: The Case of Ghana's District Assemblies. Researchjournali's Journal of Accounting, 6 (1), 1-16. Retrieved from https://www.researchjournali.com/view.php?id=4257

Shah, A. (Ed.). (2007). Budgeting and budgetary institutions. Washington D.C.: World Bank Publications. https://doi.org/10.1596/978-0-8213-6939-5

Simson, R., Sharma, N., \& Aziz, I. (2011). A guide to public financial management literature. London: Overseas Development Institute.

Uchimura, H. (2012). Health Development in the Decentralized Health System of the Philippines: Impact of Local Health Expenditures on Health. In Fiscal Decentralization and Development (pp. 73-99). Palgrave Macmillan, London. 
https://doi.org/10.1057/9780230389618_4

World Bank (2003). Case study 2-Porto Alegre, Brazil: Participatory approaches in budgeting and public expenditure management. Social Development Notes; No. 71. Washington: World Bank. Available at https://openknowledge.worldbank.org/handle/10986/11309

World Bank (2005). Public expenditure and financial accountability (PEFA): public financial management - performance measurement framework (English). Washington DC: World Bank. Available http://documents.worldbank.org/curated/en/217821468325188878/Public-expenditure-and-fi nancial-accountability-PEFA-public-financial-management-performance-measurement-frame work

World Bank (2017). Fiscal consolidation to accelerate growth and support inclusive development: Ghana public expenditure review. Retrieved from documents.worldbank.org

\section{Glossary}

PEM Public Expenditure Management

S.D Standard Deviation

\section{Copyright Disclaimer}

Copyright for this article is retained by the author(s), with first publication rights granted to the journal.

This is an open-access article distributed under the terms and conditions of the Creative Commons Attribution license (http://creativecommons.org/licenses/by/4.0/). 